\title{
Assessment Knowledge \& Practices of Health Team Working in the Blood Banks Regarding to Infection Control at Assuit City.
}

\author{
Samar F. Ahmed, Hoda D. Fahmy, Maha A. Mohammed \& Naglaa S. Abd El-Atty \\ Nursing specialist in the technical secondary school of nursing for girls in Manfaluat Egypt. \\ Professor of Community Health Nursing, Faculty of Nursing, Assuit University Egypt. \\ Professor of Clinical Pathology, Faculty of Medicine, Assuit University Egypt. \\ Lecturer of Community Health Nursing, Faculty of Nursing, Assuit University Egypt.
}

\begin{abstract}
Health care staff working in the blood banks and transfusion services are at risk of exposure to pathogenic organisms in blood.The study aimed to assess knowledge and practice of health team toward infection control in the blood banks at Assuit city.A descriptive research design was used in the study.The total number of this studied sample was 129.Two tools was used in the study; tool 1:Self-administrator questionnaire tool 2: observation check list. Results the present study found that slightly more than two-fifths of studied sample(41.1\%) had unsatisfactory knowledge about infection control. While slightly more than three-quarters of them $(75.2 \%)$ had unsatisfactory performance concerning infection control measures in the blood banks. There was a positive correlation between knowledge and performance of studied sample $(\mathrm{r}=0.132)$. While there was a negative correlation between age and years of experience with knowledge about infection control among the studied sample( $\mathrm{r}=-0.031,-0.133$ respectively).It concluded that the studied sample had poor knowledge and performance toward infection control in blood bank.Recommendations providing training program about the infection control measures and it's importance for the new employees in the blood banks. Providing continuing training courses about infection control for all health team.Distribution of a simple guide book about the infection control.
\end{abstract}

Keywords: Blood Bank, Infection Control, Knowledge, Practice \& Standard Precautions.

\section{Introduction}

Term "Blood Bank" typically refers to a division of a hospital laboratory where the storage of blood product occurs and proper testing of blood is performed to reduce the risk of transfusion-related events(Katoch,2011).Blood transfusion services in Egypt were fragmented and consisted of hospitalbased Blood Banks. These blood banks collect, process, test and issue blood products (Ahmed \& Mostafa, 2009).

Blood-banking services in Egypt are mainly hospitalbased and most hospitals obtain blood from relatives and friends of patients (replacement donors) who give their blood for the sake of a specific patient. In order to try to help, these donors may hide some information about their past medical history and may constitute a higher risk for transfusion-transmissible infections (Abdel Messih et al., 2014).In Egypt there are various kinds of donors, however, the most common four types are voluntary donors, family replacement donors, paid donor, and autologous donor (Shafei, 2013).

Blood banks are obligated to provide adequate and safe blood to the community. The safest donors are found among people who donate their blood voluntarily purely out of altruism and are self-aware of their unsuitability to serve as blood donors where there might be a slightest risk of causing health damage for blood recipients(Nwogoh et al., 2013). Health care staff working in blood banks and transfusion services are at risk of exposure to pathogenic organisms in blood in a number of ways. The major concern after occupational exposure is the possible transmission of blood-borne pathogens. Transmission of more than 20 different pathogens by needle stick and sharps injuries has been reported. Among these, hepatitis B virus (HBV), hepatitis C virus (HCV), and human immunodeficiency virus (HIV) are the most important. Infection by these viruses can lead to serious and even fatal illnesses, constituting major health care problems for health care workers. Implementation of infection control and preventive measures in blood banks are as important as in other clinical departments in the health care organizations (Abou El Enein \& El Sheriff, 2010).

Infection control refers to policies and procedures designed to provide a safe, sanitary, and comfortable environment for the client, and health care workers to minimize the risk of spreading infections.Many infection control measures, such as appropriate hand hygiene and the correct application of basic precautions during invasive procedures are simple and of low-cost, but require staff accountability and

Vol , (4) No , (9) December 2016 
behavioral change, in addition to improving staff education, reporting, and surveillance systems(Bouallègue, 2013).

The United States of America (U.S.A) and Centers for Disease Control (CDC) proposed a series of procedures for preventing occupational exposures and for handling potentially infectious materials such as blood and body fluids. These procedures, known as standard precautions (SPs), advise health care workers (HCWs) to practice regular personal hygiene; use protective barriers such as gloves and gown whenever there is contact with blood and body fluids of client; and dispose of sharps, body fluids, and other clinical wastes properly(Reda et al., 2010). Standard precautions are precautions or actions designed to prevent HCWs from being exposed to blood and deep body fluids by applying the basic principles of infection control through hand washing, utilization of appropriate protective barriers such as gloves, masks, gowns, and eye shields, safe handling and disposal of needles, and safe decontamination of instruments and other contaminated equipment(Hafizullah et al., 2014) .

The risk of infection for health care workers depends on the prevalence of diseases on clients and nature of frequency exposures. Needle-stick injuries are common accidentally expose health care workers to the blood, needle stick, my result from two hands recapping and unsafe collection of disposal waste(Galal, 2010).Factors that may determine the overall risk for occupational transmission of a blood borne pathogen include the number of infected individuals in the patient population, the chance of becoming infected after a single blood contact from an infected patient, and the type and the number of blood contacts(Bartlett, \& Weber, 2013, Kuhar et al., 2013 -Cosens , 2012).

Healthcare providers must adhere to infection prevention and control guidelines and policies at all times, and use critical thinking, risk assessment and problem-solving in managing clinical situations (Ontario Ministry of Health \& Residential care in Canada, 2011). The Center for Diseases Control, for example, has issued the Universal Precautions (UP) guidelines to protect the health care team from infection with blood borne pathogens. Strict following of these guidelines is the cornerstone of protecting health care team from infection with blood borne pathogens (Saleh et al., 2009).

The infection control nurse has multi-faceted duties. She is involved in planning, monitoring, evaluating, updating, and educating the staff infection control measures, risk of infection and major infectious diseases in the work. She sets general infection control policy, provides input into specific infection control issues and preventing outbreaks of infection in healthcare settings and the community Farrah Lee, BSN \& Natalie Lind, ACE, 2010).

\section{Significant of the study}

There are $4.9 \%$ of health care workers are exposed to needle stick per year and 24,000 and 8600 Egyptian health care team are infected yearly with hepatitis $\mathrm{C}$ virus and/or hepatitis B virus, respectively (Abd Elwahab et al., 2013).

\section{Aim of the study}

To assess knowledge and performance of health team toward infection control in the blood banks at Assuit city.

Research questions

- What is the health team's know about infection control?

- What is the current health team's performance regarding infection control?

- Is there relation between health team's knowledge about regarding infection control and their performance?

\section{Subjects \& methods}

\section{Research design}

A descriptive research design was used in this study. Study Setting

The current study conducted in the blood banks at Assuit city which are: Regional blood transfusion center at Assuit (in El-Arbeen city), El-Eman general hospital blood bank, and Assuit general hospital (ElShamlla) blood bank, El-Eman for obstetric hospital blood bank, Assuit University hospital blood bank, El-Mabarra hospital (health insurance hospital) blood bank and South Egypt Cancer Institute blood bank at Assuit.

\section{Study sample}

Convenient sample was used: The sample included all health team members working in blood banks at Assuit city. The total numbers of studied sample were 129 and divided into - 28 doctors, 22 nurses, 25 chemistrains, and 54 lab technicians. Distribution of the following health team workers in all blood banks at Assuit city 


\begin{tabular}{|c|c|c|c|c|}
\hline Places & 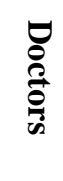 & $\begin{array}{l}Z \\
\text { Z } \\
\mathscr{B}\end{array}$ & 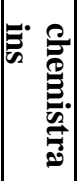 & 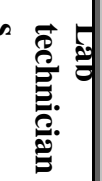 \\
\hline $\begin{array}{l}\text { Regetional blood } \\
\text { transfusion center in Assuit }\end{array}$ & 14 & 11 & 11 & 5 \\
\hline $\begin{array}{l}\text { El-Eman general hospital } \\
\text { blood bank }\end{array}$ & 3 & 1 & - & 14 \\
\hline $\begin{array}{l}\text { Assuit general hospital } \\
\text { blood bank. }\end{array}$ & 2 & - & - & 7 \\
\hline $\begin{array}{l}\text { El-Eman for obstetric } \\
\text { hospital blood bank }\end{array}$ & 2 & 2 & - & 8 \\
\hline $\begin{array}{l}\text { Assuit University hospital } \\
\text { blood bank }\end{array}$ & 4 & 4 & 5 & 9 \\
\hline $\begin{array}{l}\text { El-Mabarra hospital blood } \\
\text { bank }\end{array}$ & 1 & - & 5 & 5 \\
\hline $\begin{array}{l}\text { South Egypt cancer institute } \\
\text { blood bank at Assuit. }\end{array}$ & 2 & 4 & 4 & 6 \\
\hline Total & 24 & 22 & 25 & 54 \\
\hline
\end{tabular}

Study tools

Two tools were used to collect data for the present study

\section{Tool 1}

Self-administrator questionnaire sheet was developed by the researchers to collect information from the participants was included two parts:-

\section{Part 1: Personal characteristics of health care} team

It was included personal characteristics of health care team as age, academic qualification, job, sex, years of experience, marital status, attendance of conferences or educational training courses about infection control and immunization against hepatitis B virus.

Part 2: Knowledge of health care team about infection control in blood banks:

Such as definition of infection, infection control ,general universal precaution of infection control, knowledge about sources of infection in blood banks and cleaning up splashing of blood, knowledge about hand washing, personal protective equipment(mask,gloves,apron and goggles),disposal of lancets, strips, lab tubes and donated needles, methods of wastes disposal (contaminated and un contaminated wastes).

\section{Tool 2}

Observation check list was developed by researchers as hand washing, wearing gloves, change gloves between donors and steps of hand washing and removing gloves.

\section{Scoring system}

Score system in both knowledge and performance a correct response was scored (1) grade and zero for uncorrected response (satisfactory $\geq 50 \%$ and unsatisfactory <50\%) (Ragab, 2015).

Validity of tools

The tools were reviewed by five experts from medical and nursing staff at Assuit University to assess and evaluate the tools' items to secure the validity of tools.

\section{Methodology}

I-Administrative phase

An official letter of approval which was obtained from the Dean of the Faculty of Nursing- Assuit University was sent to the directors of the selected blood banks of the Ministry of Health, Assuit University Hospitals and Health Insurance to carry out the study in the selected places. That letter included explanation of the purpose and the nature of the study and permission to carry out this research.

II-Pilot Study

Pilot study was carried out before starting the data collection phase on $10 \%$ of health team who were included in the studied sample to test clarity of tools and to estimate the time needed to fulfill the study tools.

III- Data collection Phase

Ethical Considerations

Informed consent for participation in the study was taken from each participant after full explanation of the purpose of the study. They were informed that their participation in this study was voluntarily. The participants were given opportunity to refuse participation and they were informed that they could withdraw at any stage of the data collection without given any reason. The studied sample was assured that any information collected would be confidential and used for the research purpose only.

\section{Field work}

- Data was collected in the period from $21^{\text {st }}$ of February,2015 to $4^{\text {th }}$ of August, 2015.The researchers interviewed each person individually according to his/her work circumstances to obtain the necessary information after introducing the researchers themselves and explaining the purpose of the study. Every week about from 4 to 6 sheets was finished and data collected three days /week. The average of time taken for completing each questionnaire was around 15-20 minutes depending on the persons' responses to question.

- Observation check list is done by the researchers themselves. They were staying at morning shift to assess doctors', nurses', chemistrains' and lab technicians' performance before, during and after finishing the work towards universal infection control measures on the actual and clinical situation of their work. 
Statistical analysis

The data obtained was reviewed, prepared for computer entry, coded, analyzed and tabulated.Descriptive statistics (i.e., frequencies, percentage, mean, standard deviation, etc)was done by using software package for statistical Science (SPSS)
Version 11.

Chi-square test and correlation were used to compare differences in the distribution of frequencies among different groups, it is considered significant when $\mathrm{P}<0.05$.

\section{Results}

Table (1): Distribution of the studied sample regarding to their personal characteristics in blood bank at Assuit city, 2015.

\begin{tabular}{|c|c|c|}
\hline personal characteristics & No. $(n=129)$ & $\%$ \\
\hline \multicolumn{3}{|l|}{ Sex } \\
\hline Male & 62 & 48.1 \\
\hline Female & 67 & 51.9 \\
\hline \multicolumn{3}{|l|}{ Age } \\
\hline$<30$ years & 54 & 41.9 \\
\hline $30-35$ years & 36 & 27.9 \\
\hline$>35$ years & 39 & 30.2 \\
\hline Mean \pm SD (Range) & \multicolumn{2}{|c|}{$33.72 \pm 8.47(21.0-57.0)$} \\
\hline \multicolumn{3}{|l|}{ Marital status } \\
\hline Single & 28 & 21.7 \\
\hline Married & 97 & 75.2 \\
\hline Divorced & 3 & 2.3 \\
\hline Widow & 1 & 0.8 \\
\hline \multicolumn{3}{|l|}{ Academic qualification: } \\
\hline Secondary school of nursing & 19 & 14.7 \\
\hline Health technical institute & 57 & 44.2 \\
\hline Baccalaureates(medical, nursing and science) & 53 & 41.1 \\
\hline \multicolumn{3}{|l|}{ Years of experience } \\
\hline$<5$ years & 40 & 31.0 \\
\hline $5-10$ years & 47 & 36.4 \\
\hline$>10$ years & 42 & 32.6 \\
\hline Mean \pm SD (Range) & \multicolumn{2}{|c|}{$9.11 \pm 6.87(1.0-35.0)$} \\
\hline \multicolumn{3}{|l|}{ Occupation } \\
\hline Nurse & 22 & 17.1 \\
\hline Lab technician & 54 & 41.8 \\
\hline Physician & 28 & 21.7 \\
\hline Chemistrain & 25 & 19.3 \\
\hline \multicolumn{3}{|l|}{ Attending training on infection control } \\
\hline Yes & 42 & 32.6 \\
\hline No & 87 & 67.4 \\
\hline \multicolumn{3}{|l|}{ Immunization against $\mathrm{HBV}$} \\
\hline Yes & 88 & 68.2 \\
\hline No & 41 & 31.8 \\
\hline \multicolumn{3}{|l|}{ Sources of providing vaccination } \\
\hline Hospital where you work & 77 & 87.5 \\
\hline Health insurance & 7 & 8.0 \\
\hline Non-governmental places & 4 & 4.5 \\
\hline \multicolumn{3}{|l|}{ Role in blood bank } \\
\hline Make phlebotomy process/phlebotomy department & 64 & 49.6 \\
\hline
\end{tabular}




\begin{tabular}{|c|c|c|}
\hline personal characteristics & No. $(n=129)$ & $\%$ \\
\hline Work in serological department & 33 & 25.6 \\
\hline Work in component department & 25 & 19.4 \\
\hline Work in issuing department & 52 & 40.3 \\
\hline Work in cross-matching department & 37 & 28.7 \\
\hline \multicolumn{3}{|l|}{ Exposure to needle stick injury } \\
\hline Yes & 17 & 13.2 \\
\hline No & 112 & 86.8 \\
\hline \multicolumn{3}{|l|}{ In case of exposure to needle stick injury:n=17 } \\
\hline No action & 2 & 11.8 \\
\hline Squeeze the injury site & 8 & 47.1 \\
\hline Wash the injury site with running water & 11 & 64.7 \\
\hline Disinfect the injury site with antiseptic solution & 6 & 35.3 \\
\hline Put dressing on the injury site & 8 & 47.1 \\
\hline
\end{tabular}

* More than one answer was selected.

Table (2) Distribution of the studied sample regarding to knowledge about infection control in blood banks at Assuit city, 2015.

\begin{tabular}{|c|c|c|}
\hline Knowledge about infection & No. $(n=129)$ & $\%$ \\
\hline \multicolumn{3}{|l|}{ Meaning of infection } \\
\hline Correct & 76 & 58.9 \\
\hline Incorrect & 53 & 41.1 \\
\hline \multicolumn{3}{|l|}{ Meaning of infection control } \\
\hline Correct & 55 & 42.6 \\
\hline Incorrect & 74 & 57.4 \\
\hline \multicolumn{3}{|l|}{ * General precaution for infection control } \\
\hline None & 25 & 19.4 \\
\hline Hand washing & 82 & 63.6 \\
\hline Personal protective equipment & 91 & 70.5 \\
\hline Infection control & 14 & 10.9 \\
\hline Equipment sterilization and disinfection & 5 & 3.9 \\
\hline Cleaning the work environment & 30 & 23.3 \\
\hline Waste disposal & 28 & 21.7 \\
\hline Occupational safety and health & 8 & 6.2 \\
\hline \multicolumn{3}{|l|}{ Source of infection in blood banks } \\
\hline Needle stick injury & 61 & 47.3 \\
\hline Blood and its component & 100 & 77.5 \\
\hline \multicolumn{3}{|l|}{ Action was taken in case of blood splash. } \\
\hline Wear personal protective equipment & 8 & 6.2 \\
\hline $\begin{array}{l}\text { Clean the floor with towel then throw it in } \\
\text { contaminated waste basket }\end{array}$ & 29 & 22.5 \\
\hline Clean the floor with concentrated choler & 82 & 63.6 \\
\hline Clean the floor with water and available detergent & 41 & 31.8 \\
\hline Dry the floor & 20 & 15.5 \\
\hline \multicolumn{3}{|c|}{ Presences of written rules for infection control in your workplace } \\
\hline Yes & 110 & 85.3 \\
\hline No & 19 & 14.7 \\
\hline \multicolumn{3}{|l|}{ Carefully reading that rules } \\
\hline Yes & 93 & 72.1 \\
\hline No & 36 & 27.9 \\
\hline \multicolumn{3}{|l|}{ Source of information about infection control } \\
\hline From curriculum in their studies & 13 & 14.0 \\
\hline
\end{tabular}




\begin{tabular}{|c|c|c|}
\hline Knowledge about infection & No. $(n=129)$ & $\%$ \\
\hline Books and magazines & 7 & 7.5 \\
\hline Seminars and conferences & 17 & 18.3 \\
\hline Manual of infection control on work place & 60 & 64.5 \\
\hline Internet & 26 & 28.0 \\
\hline
\end{tabular}

* More than one answer was selected

Table (3) Distribution of the studied sample's performance regarding infection control measures in donation department in blood banks at Assuit city 2015. $\mathrm{N}=64$.

\begin{tabular}{|c|c|c|c|c|}
\hline \multirow{2}{*}{ Item } & \multicolumn{2}{|c|}{ Done } & \multicolumn{2}{|c|}{ Not done } \\
\hline & No. & $\%$ & No. & $\%$ \\
\hline Donation area is used only for donation & 52 & 81.2 & 12 & 18.8 \\
\hline Any guidelines or standard operation procedures (SOPS) are available. & 44 & 68.8 & 20 & 31.2 \\
\hline A separated clean area for phelopetomy process & 41 & 64.1 & 23 & 35.9 \\
\hline Staff wash his/her hand before examining donors & 1 & 1.6 & 63 & 98.4 \\
\hline Hand washing is done before and after examining donor & 1 & 1.6 & 63 & 98.4 \\
\hline Hand washing done in between examination of donors & 0 & 0.0 & 64 & 100.0 \\
\hline Hand washing before wear gloves and after remove it & 0 & 0.0 & 64 & 100.0 \\
\hline Nurse makes hand washing before and after donation process & 0 & 0.0 & 64 & 100.0 \\
\hline Staff wear gloves & 43 & 67.2 & 21 & 32.8 \\
\hline they change gloves between donors & 24 & 37.5 & 40 & 62.5 \\
\hline Staff wearing eye glass during the procedure of pheleptomy. & 1 & 1.6 & 63 & 98.4 \\
\hline Staff reuse lancet for more than one donor. & 3 & 4.7 & 61 & 95.3 \\
\hline Venipuncture site is disinfected & 37 & 57.8 & 27 & 42.2 \\
\hline The staff use 70\% alcohol as disinfection. & 40 & 62.5 & 24 & 37.5 \\
\hline The disinfected procedure is done in Circular motion from inner to outer. & 12 & 18.8 & 52 & 81.2 \\
\hline Closed system is applied during phelopetomy process & 34 & 53.1 & 30 & 46.9 \\
\hline Anew bag is used for every venipuncture & 64 & 100 & $\mathrm{o}$ & 0 \\
\hline The staff recap needles after the donation procedure. & 55 & 85.9 & 9 & 14.1 \\
\hline Staff put used needles in the right box. & 52 & 81.2 & 12 & 18.8 \\
\hline \multicolumn{5}{|l|}{ The blood bag is labeled with } \\
\hline Donation date & 64 & 100.0 & 0 & 0.0 \\
\hline Donation number & 62 & 96.9 & 2 & 3.1 \\
\hline Blood group & 48 & 75.0 & 16 & 25.0 \\
\hline Expire date & 23 & 35.9 & 41 & 64.1 \\
\hline Venipuncture site is covered with bandage during donation & 9 & 14.1 & 55 & 85.9 \\
\hline
\end{tabular}

* More than one answer was selected.

Table (4): Distribution of the studied sample's performance regarding infection control measures in (component, serology, and issuing laboratories in blood banks at Assuit city 2015. N=96.

\begin{tabular}{|c|c|c|c|c|}
\hline \multirow{2}{*}{ Items } & \multicolumn{2}{|c|}{ Done } & \multicolumn{2}{|c|}{ Not done } \\
\hline & No. & $\%$ & No. & $\%$ \\
\hline Hand washing is done before and after wearing gloves. & 1 & 1.0 & 95 & 99.0 \\
\hline Standard operating procedures (SOPs) are available. & 63 & 65.6 & 33 & 34.4 \\
\hline Authorized person is present. & 66 & 68.8 & 30 & 31.2 \\
\hline Staff wearing lab uniform/coat & 76 & 79.2 & 20 & 20.8 \\
\hline Using soap for hand washing. & 82 & 85.4 & 14 & 14.6 \\
\hline Using paper towel for drying hands. & 7 & 7.3 & 89 & 92.7 \\
\hline \multicolumn{5}{|l|}{ * Using available material for waste disposal } \\
\hline Safety box for sharps & 93 & 96.9 & 3 & 3.1 \\
\hline
\end{tabular}




\begin{tabular}{|l|c|c|c|c|}
\hline \multirow{2}{*}{ Items } & \multicolumn{2}{c|}{ Done } & \multicolumn{2}{c|}{ Not done } \\
\cline { 2 - 5 } & No. & \% & No. & \% \\
\hline Container for fluid waste & 15 & 15.6 & 81 & 84.4 \\
\hline General waste basket & 48 & 50.0 & 48 & 50.0 \\
\hline Others & 3 & 3.1 & 93 & 96.9 \\
\hline Eating food or drinks in labe & 54 & 56.2 & 42 & 43.8 \\
\hline Clean the working surface before starting the work. & 6 & 6.2 & 90 & 93.8 \\
\hline It is cleaned, with & \multicolumn{4}{|c|}{} \\
\hline Chlorox & 16 & 16.7 & 80 & 83.3 \\
\hline Alcohol & 11 & 11.5 & 85 & 88.5 \\
\hline Savlon & 10 & 10.4 & 86 & 89.6 \\
\hline Water only & 10 & 10.4 & 86 & 89.6 \\
\hline Others & 10 & 10.4 & 86 & 89.6 \\
\hline Cleaning the working surface after finishing the work. & 21 & 21.9 & 75 & 78.1 \\
\hline Staff wear gloves during working & 85 & 88.5 & 11 & 11.5 \\
\hline Checking expiry dates of kits /reagent are checked & 77 & 80.2 & 19 & 19.8 \\
\hline Equipment checked before procedure. & 42 & 43.8 & 54 & 56.2 \\
\hline Hand washing after finishing the procedure & 39 & 40.6 & 57 & 59.4 \\
\hline
\end{tabular}

* More than one answer was selected.

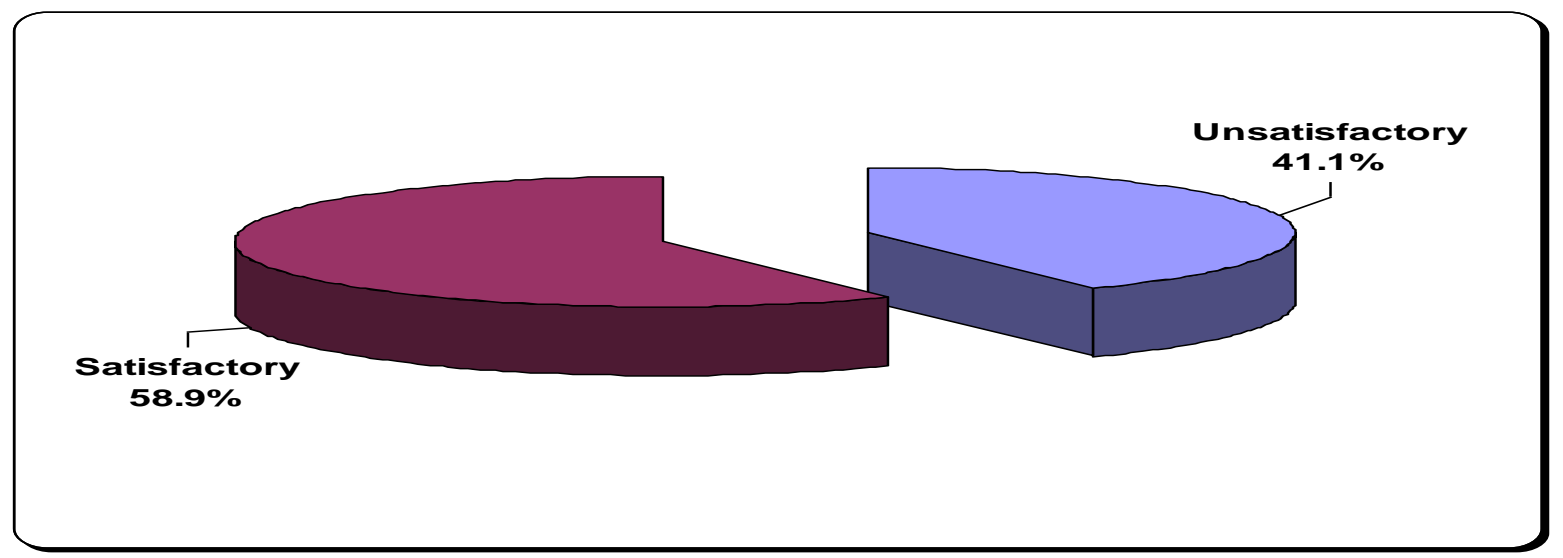

Fig. (1): Total scoring of knowledge of the studied sample regarding infection control in blood bank at Assuit city 2015.

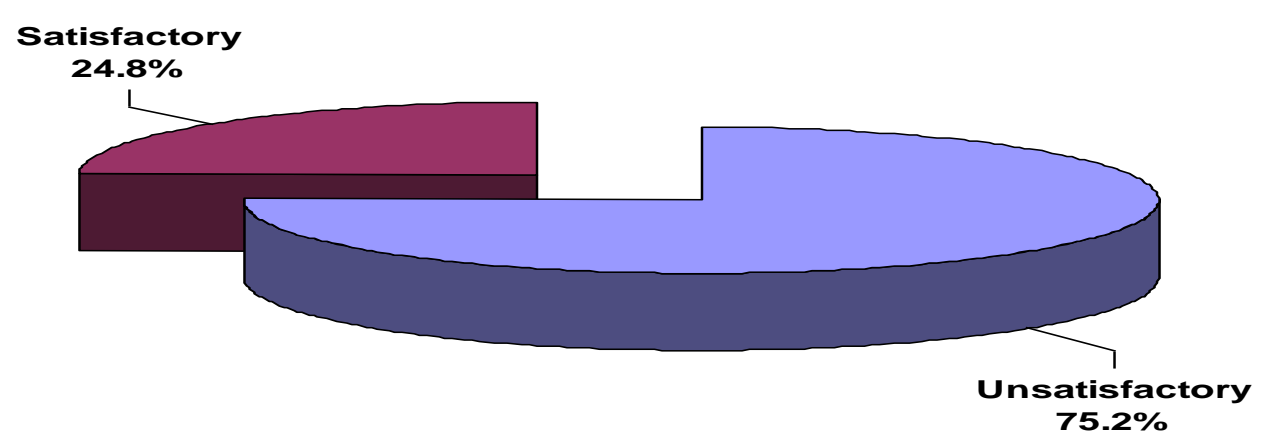

Fig. (2): Total scoring of the studied sample performance regarding measures which should be taken for infection control in blood banks at Assuit city 2015. 
Table (5): Relation between total score of knowledge about infection control measures and personal characteristics among studied sample in blood banks at Assuit city, 2015.

\begin{tabular}{|c|c|c|c|c|c|c|}
\hline & \multicolumn{4}{|c|}{ Level of knowledge } & \multirow{3}{*}{$\mathbf{X}^{2}$} & \multirow{3}{*}{ P-value } \\
\hline & \multicolumn{2}{|c|}{ Unsatisfactory } & \multicolumn{2}{|c|}{ Satisfactory } & & \\
\hline & No.(53) & $\%$ & No.(76) & $\%$ & & \\
\hline \multicolumn{5}{|l|}{ Sex } & \multirow{3}{*}{0.029} & \multirow{3}{*}{0.866} \\
\hline Male & 25 & 40.3 & 37 & 59.7 & & \\
\hline Female & 28 & 41.8 & 39 & 58.2 & & \\
\hline \multicolumn{5}{|l|}{ Age } & \multirow{4}{*}{2.315} & \multirow{4}{*}{0.314} \\
\hline$<30$ years & 24 & 44.4 & 30 & 55.6 & & \\
\hline $30-35$ years & 11 & 30.6 & 25 & 69.4 & & \\
\hline$>35$ years & 18 & 46.2 & 21 & 53.8 & & \\
\hline \multicolumn{5}{|l|}{ Academic qualification } & \multirow{4}{*}{14.110} & \multirow{4}{*}{$0.001 *$} \\
\hline Secondary school of nursing & 8 & 42.1 & 11 & 57.9 & & \\
\hline Health technical Institute & 33 & 57.9 & 24 & 42.1 & & \\
\hline Baccalaureates(medicine, nursing andscience) & 12 & 22.6 & 41 & 77.4 & & \\
\hline \multicolumn{5}{|l|}{ Years of experience } & \multirow{4}{*}{3.389} & \multirow{4}{*}{0.184} \\
\hline$<5$ years & 15 & 37.5 & 25 & 62.5 & & \\
\hline $5-10$ years & 16 & 34.0 & 31 & 66.0 & & \\
\hline$>10$ years & 22 & 52.4 & 20 & 47.6 & & \\
\hline \multicolumn{5}{|l|}{ Occupation } & \multirow{5}{*}{13.701} & \multirow{5}{*}{$0.003^{*}$} \\
\hline Nurse & 9 & 40.9 & 13 & 59.1 & & \\
\hline Lab technician & 32 & 58.2 & 23 & 41.8 & & \\
\hline Physician & 7 & 25.0 & 21 & 75.0 & & \\
\hline Chemistrain & 5 & 20.8 & 19 & 79.2 & & \\
\hline \multicolumn{5}{|c|}{ Attending seminars or conferences in infection control } & \multirow{3}{*}{0.444} & \multirow{3}{*}{0.505} \\
\hline Yes & 19 & 45.2 & 23 & 54.8 & & \\
\hline No & 34 & 39.1 & 53 & 60.9 & & \\
\hline \multicolumn{5}{|l|}{ Attending training courses in infection control } & \multirow{3}{*}{0.912} & \multirow{3}{*}{0.402} \\
\hline Yes & 13 & 48.1 & 14 & 51.9 & & \\
\hline No & 40 & 39.2 & 62 & 60.8 & & \\
\hline
\end{tabular}

Table (6): Relation between total score of performance about infection control measures among studied sample and personal characteristics in blood banks at Assuit city, 2015.

\begin{tabular}{|c|c|c|c|c|c|c|}
\hline \multirow{3}{*}{ Items } & \multicolumn{4}{|c|}{ Level of performance } & \multirow{3}{*}{$\mathbf{X}^{2}$} & \multirow{3}{*}{ P-value } \\
\hline & \multicolumn{2}{|c|}{ Unsatisfactory } & \multicolumn{2}{|c|}{ Satisfactory } & & \\
\hline & No.(97) & $\%$ & No.(32) & $\%$ & & \\
\hline \multicolumn{5}{|l|}{ Sex } & \multirow{3}{*}{6.776} & \multirow{3}{*}{$0.009 *$} \\
\hline Male & 53 & 85.5 & 9 & 14.5 & & \\
\hline Female & 44 & 65.7 & 23 & 34.3 & & \\
\hline \multicolumn{5}{|l|}{ Age } & \multirow{4}{*}{7.148} & \multirow{4}{*}{$0.028 *$} \\
\hline$<30$ years & 39 & 72.2 & 15 & 27.8 & & \\
\hline $30-35$ years & 23 & 63.9 & 13 & 36.1 & & \\
\hline$>35$ years & 35 & 89.7 & 4 & 10.3 & & \\
\hline \multicolumn{5}{|l|}{ Academic qualification } & \multirow{4}{*}{11.175} & \multirow{4}{*}{$0.004 *$} \\
\hline Diploma of nursing & 15 & 78.9 & 4 & 21.1 & & \\
\hline Technical Institution of health & 50 & 87.7 & 7 & 12.3 & & \\
\hline $\begin{array}{l}\text { Baccalaureate(medicine, nursing and } \\
\text { science) }\end{array}$ & 32 & 60.4 & 21 & 39.6 & & \\
\hline Years of experience & & & & & 7.987 & $0.018^{*}$ \\
\hline
\end{tabular}




\begin{tabular}{|c|c|c|c|c|c|c|}
\hline \multirow{3}{*}{ Items } & \multicolumn{4}{|c|}{ Level of performance } & \multirow{6}{*}{$\mathbf{X}^{2}$} & \multirow{6}{*}{ P-value } \\
\hline & \multicolumn{2}{|c|}{ Unsatisfactory } & \multicolumn{2}{|c|}{ Satisfactory } & & \\
\hline & No.(97) & $\%$ & No.(32) & $\%$ & & \\
\hline$<5$ years & 28 & 70.0 & 12 & 30.0 & & \\
\hline $5-10$ years & 31 & 66.0 & 16 & 34.0 & & \\
\hline$>10$ years & 38 & 90.5 & 4 & 9.5 & & \\
\hline \multicolumn{5}{|l|}{ Occupation } & \multirow{5}{*}{11.784} & \multirow{5}{*}{$0.008^{*}$} \\
\hline Nurse & 18 & 81.8 & 4 & 18.2 & & \\
\hline Lab technician & 48 & 87.3 & 7 & 12.7 & & \\
\hline Doctor & 16 & 57.1 & 12 & 42.9 & & \\
\hline Chemistrain & 15 & 62.5 & 9 & 37.5 & & \\
\hline \multicolumn{5}{|c|}{ Attending seminars or conferences in infection control } & \multirow{3}{*}{5.896} & \multirow{3}{*}{$0.015^{*}$} \\
\hline Yes & 26 & 61.9 & 16 & 38.1 & & \\
\hline No & 71 & 81.6 & 16 & 18.4 & & \\
\hline \multicolumn{5}{|c|}{ Attending training courses in infection control branch: } & \multirow{3}{*}{0.391} & \multirow{3}{*}{0.249} \\
\hline Yes & 18 & 66.7 & 9 & 33.3 & & \\
\hline No & 79 & 77.5 & 23 & 22.5 & & \\
\hline
\end{tabular}

Table (1): Shows the personal characteristics of the studied sample in blood banks at Assuit city.It was clear that $51.9 \%$ of the studied sample were female. Also, $41.9 \%$ of them aged less than 30 years, the table also illustrates that $75.2 \%$ were married, $44.2 \%$ of the studied sample graduated from Health Technical Institute. While $14.7 \%$ of them had a secondary school of nursing.

Also, this table illustrated that $36.4 \%$ the studied sample had job experience from 5 to 10 years.Concerning to their occupation, $42.6 \%$ of studied sample were a lab technician, while $17.1 \%$ of them were nurses. Also, this table show that $32.6 \%$ them were attended training on infection control. This table also reveals that more than $68.2 \%$ were immunized against hepatitis B virus and $87.5 \%$ of them were taken hepatitis $\mathrm{B}$ vaccine from the place where they are worked. Also, this table reported that $13.2 \%$ of studied sample were exposed to needle stick injury. Concerning to action which should be taken after needle stick injury, less than $64.7 \%$ were washing the injury site with running water, while $11.8 \%$ of them didn't take any action.

Table (2): Illustrate knowledge of study sample regarding to infection control in blood banks at Assuit city. It reveals that $58.9 \%$ of studied sample had correct knowledge about the definition of infection, while $42.6 \%$ had correct knowledge about definition of infection control. This table shows more than $77.5 \%$ were reported that blood and its components are sources of infection in blood banks, and $47.3 \%$ reported that needle stick injury is the source of infection in blood banks. Concerning to actions taken in case of blood splash this table revealed that only $6.2 \%$ of studied sample were wearing personal protective equipment. While $63.6 \%$ clean the floor with concentrated choler. Also, this table shows $85.3 \%$ had written rules for infection control in their workplace.

Table (3): Reveals the distribution of the study sample's practice regarding infection control measures in donation department in blood banks at Assuit city. It was observed that $81.2 \%$ of the studied samples used donation area only for donation. $68.8 \%$ of studied sample has guidelines or standard operation procedures (SOPS) in their work place. It was also noticed that $98.4 \%$ of studied sample didn't make hand washing before and after examining the donors. Also, $67.2 \%$ of studied sample wearing gloves, but $37.5 \%$ were changing gloves between the donors. $95.3 \%$ of studied sample didn't reuse lancet .Also, this table shows that $57.8 \%$ of studied sample disinfected venipuncture site. $85.9 \%$ of studied sample were recapping needles after the donation procedure. While $81.2 \%$ put used needles in the right box.

Table (4): Illustrate studied sample's practice regarding to infection control measures in laboratory in blood banks. Also, $99.0 \%$ of studied sample who worked in laboratory didn't make hand washing before and after wearing gloves. While $65.6 \%$ of studied sample who worked in laboratory had available Standard Operating Procedures (SOPs). $79.2 \%$ of studied sample wearing lab uniform, and $85.4 \%$ using soap for hand washing , while $92.7 \%$ were using paper towel for drying hands after washing.Regarding to the availability of materials for waste disposal, $96.9 \%$ had safety box for sharps, and $84.4 \%$ there is not available containers for fluid waste.But only $6.2 \%$ of studied sample cleaning the working surface before starting the work. 
Table (5): Reveals Relation between total score of knowledge about infection control measures and personal characteristics among studied sample in blood banks at Assuit city. It shows that there is statistical significant difference between knowledge of studied sample about infection control measures in blood banks and their academic qualification and their occupation p-value (0.001 - 0.003 respectively).

Table (6): Illustrated that relation between total score of performance about infection control measures and personal characteristics among studied sample in blood banks at Assuit city. It was observed that there is statistical significant difference between level of performance of them about infection control measures in blood banks and their sex, age, academic qualification, years of experience, occupation, and attending seminars or conferences in infection control p-value $(0.009,0.028,0.004,0.018,0.008$ and 0.015 respectively).

Fig. (1): Total scoring of knowledge of health team regarding infection control in blood bank at Assuit city 2015 .

Fig. (2): Total scoring of studied sample performance regarding measures of infection control in blood banks at Assuit city 2015.

\section{Discussion}

The Centers for Disease Control (CDC) estimates that 5.6 million workers in the healthcare industry and related occupations are at risk of occupational exposure to blood borne pathogens, including human immunodeficiency virus (HIV), hepatitis B virus (HBV), hepatitis C virus (HCV), and others (Occupational Safety \& Health Administration (OSHA), 2014).

Regarding to socio-demographic characteristics of the health team members. the present study revealed that more than two fifth of participants belonged to age group $(<30)$ years old this finding disagreed with (Girgis et al., 2013) who found that more than threequarters of studied sample aged between 20 to 30 years old. Pertaining to population of the study, more than half of studied sample were females. This finding is in line with (Girgis et al, 2013) who reported that more than half of participants were female.

The current result revealed that nearly one-third of studied sample had attended conference related to infection control, these findings agreed with (Mohamed,2010) who reported that more than two fifth of participants had attended conference related to infection control due to limit number of health team in blood bank so, it is difficult to leave work for attend training program about infection control.
Also the present study indicated that more than one tenth of studied sample exposed to needle stick injury, these result agreed with (Nour Eldien \& Ali, 2016) who found that less than one-fifth of all participants reported exposure to needle stick or blood splash, but these result disagreed with (AllMurr,2013) who reported that less than one-half of studied participants were exposed to needle stick injury, and also disagreed with Egyptian study by (Saleh et al., 2009) who reported about one-third of one or more exposure. The variation in exposure from one study to another could be related to workload in the different settings and the safe procedures used to reduce the risk of exposure and could be related to the best practice of no needle recapping among the participants in the current study. Concerning to studied samples' performance of infection control measures in donation department. The present study revealed that fewof studied sample of health team members who work in pheleptomy department perform hand washing before and after examine the donors these results in agreement with (Abou El Enein \& El sheriff, 2010) who found that none of the studied sample (physicians, nurses or technicians )washes their hands between donors while these findings disagreed with (All Murr, 2013) who reported that near of three-quarters of participants always washed their hands before and after contact with clients. Also, all Nurses who work in pheleptomy department didn't perform hand washing before and after donation process. These results are similar to (El Houfey, 2007) who found that less than nine-tenths of nurses didn't perform hand washing before patient's treatment and about four-fifths didn't perform hand washing after patient's treatment, these findings are disagreed with (All Murr, 2013 and Labrague et al., 2012) who reported that the vast majority of participants always washed their hands after exposure to blood fluid or body fluid due to insufficient knowledge about importance of hand washing before and after contact with client or donor and lake of supervision of authorized person .

Regarding to personal protective equipment the current study found that more than two-thirds of studied sample who work in pheleptomy department worn gloves, only more than one-third who change the gloves between the donors these results in agreement with (All Murr,2013)who reported that slightly more than two-fifths of participants always wore gloves when withdrawing blood and vein puncture process, these results in line with other study conducted by (Mohamed, 2010) who found that about half of studied sample wore gloves and slightly more than two-fifths of studied sample change gloves after each patient. But these results in contrast with (Abou El Enein \& El sheriff,2010) 
who found changing gloves in between donors is rarely done by most of blood bank workers. That may be due to insuffient equipments and over load of work.

The present study found that all studied sample who worked in phelptomy department are used a new bag is used for every venipuncture that similar to (Mohamed, 2010) who found that the vast majority of studied sample used anew syringe for each injection.

Regarding studied samples' practice of infection control measures in laboratories. The current study reported that few of studied sample worked in laboratories departments who washed their hands before and after removed the gloves ,these results are similar to (Abou El-Enein \& El Mahdy, 2011) who found that few of participants who washed their hands or alcohol rub after removing gloves ( 7 out of 190 opportunities).Also agree with (Amoran, \& Onwube, 2013) who reported that few of studied sample were doing hand washing before wearing the gloves, and slightly more than one tenth of studied sample wash hands after removal of gloves. The present study disagreed with (Abou El Enein \& El sherif, 2010)who found that all technicians kept washing their hands before leaving the laboratory working area, that may be due to the lake of knowledge about the purpose and importance of hand washing for safe their self from infection.

The recent study found that about two-thirds of studied sample worked in the lab had Standard Operating Procedures (SOPs) that result disagreed with (Abou El Enein \& El sherif, 2010) who reported that no availability of Standard Operating Procedures (sops) in the blood bank labs.

The presented study also reported that the majority of studied sample worked in lab worn gloves during their working in lab these results agreed with (Abou El Enein \& Elheriff ,2010) who revealed that nearly four fifths of studied sample wore gloves during work in laboratories. The present study also observed that vast majority of studied sample worked in lab had safety box for sharps these findings are disagreed with (Amoran, and Onwube, 2013) who observed few of studied sample had a sharp disposal system in their various workplaces.

Regarding to knowledge and awareness about universal precautions among studied sample of health team members, the present study showed that less than three fifths of them had satisfactory knowledge regarding infection control measures and slightly more than two fifths of them had unsatisfactory knowledge regarding infection control measures these results in a line with (El-Houfy, 2007 \& Vaz1 et al., 2010) who found that the level of knowledge among health care team was satisfactory regarding infection control. But these results disagreed with (El Sayd et al., 2014), who reported that the majority of the participants had a low to moderate level of knowledge about infection control.

As regard the Relation between level of knowledge and personal characteristics of studied sample, the current study revealed that there was no significant statistical study between knowledge with sex of studied participants of health care team p-value $(0$. 866). These findings were in contrast to study of (EllMurr 2013), who found that there was a significant correlation between knowledge about universal precautions and gender of participants pvalue(0.0001). These results may be due to lake enough training programs about infection control.

Concerning to age, years of experience and training course, the current study revealed that there was no significant statistical study between knowledge and age, training course and years of experience of studied participants of health team, these findings were in agreement with (Fashafsheh, et al., 2015 )who reported that there is no relationship between knowledge regarding infection control and age, years of experience, and training course of the studied group. These results may be due to insufficient training courses in infection control, lack of periodic refreshment courses about update knowledge and infection control or reading update knowledge toward infection control and absence of guidance.

In relation to academic qualification, the present study revealed that there was significant association between knowledge toward infection control and academic qualification of studied sample pvalue(0.001).These results disagreed with (Ell Murr, 2013) who found that there are not significant between different academic degrees or academic qualification and knowledge about standard precautions(SPs) measures of different educational levels of participants. These results may be due to they had knowledge about infection control in their curriculums during their study every one as the level of academic degrees.

Regarding to level of performance of studied sample the present study found that unsatisfactory performance among three quarters of studied sample had unsatisfactory level of performance and only about one quarter had satisfactory level of performance, These findings are in the same line with several studies carried out by (Mohamed, 2010, ElHoufey, 2007 \& Gamal, 2005) who found that most of health team workers have poor performance related to infection control. Also disagreed with (Yakob et al., 2015) who found that practice of health care workers was not sufficient to standard level of universal/standard precaution. These findings may be attributed to lack of supervision from senior 
staff, work overload, and insufficient training program about infection control or workshop.

The current study found that there was significant statistical association between performance level of standard precautions measures and gender of studied sample, these findings are disagreed with (El Murr, 2013) who reported that no statistically significant association between practice level of standard precautions measures and gender of participants .

\section{Conclusion}

Based on the results of the present study, it was concluded that: It concluded that the health team had unsatisfactory knowledge and performance toward infection control in blood bank.

\section{Recommendations}

Based on the previous findings of the present study, the following recommendations are suggested

- Providing training program about the infection control masseurs and its important for new employees of health care team in blood banks.

- Providing continuous refreshment training courses about infection control programs and about evidence-based practice in infection control for all health care team.

- Providing closed supervision from infection control team to health care team working in blood banks.

- Availability of guide book for the health team containing updating knowledge and performance in the field.

\section{References}

1. Abd Elwahab S., Mohamed H., Galal I., Sobhy M., Abdel-Ghaffar T., Galal G., Mikhail M, El-Kamary S., Waked I., \& Thomas G.,(2013):Incidence of hepatitis C virus infection among Egyptian healthcare workers at high risk of infection, Journal of Clinical Virology V 57(1): 24-8. doi: 10.1016/j.jcv.2013.01.005. Epub 2013 Jan 29.

2. Abdel Messih I., Ismail M., Saad A., \& Azer M., (2014): The degree of safety of family replacement donors versus voluntary nonremunerated donors in an Egyptian population, Blood Transfuse journal v12(2): 159-165.

3. Abou El Enien N., \& El sheriff A., (2010): Infection Control Practices in A University Blood Bank, Alexandria, Egypt. Thesis submitted for partial fulfillment of the requirements for the master degree of health administration and behavioral sciences, High Institute of Public Health, Alexandria University,
Egypt. Bulletin of High Institute of Public Health journal Vol.40( 2).

4. Abou El-enein N., \& EIMahdy H., (2011): Standard precautions: knowledge , attitude and practice study among nurses in the dialysis unit in a university hospital in Alexandria, Egypt. Journal of Egypt public health Association. Volum 86 (1-2):pp3-10.

5. Ahmed A., \& Moftah F., (2009): Egyptian national blood transfusion services conversion plan, Blood Transfuse journal, Volume 96, Issue Supplement s1.

6. AllMurr B., (2013): Knowledge and practice of standard precaution and sharp injures among nurses in the Northern West Bank Hospitals. Thesis submitted for partial fulfillment of the requirements for the master degree of public health, Faculty of Graduate studies, An-Najah National University, Nablus, Palestine.2013.

7. Amoran E., \& Onwube O., (2013): Infection control and practice of standard precautions among healthcare workers in northern Nigeria. Journal of Global Infectious Diseases Volume: 5 | Issue: 4 | Page: 156-163.

Availableat:http://www.osha.gov/pls/oshaweb/owadis p.show_document?p_table=STANDARDS\&p_id $=100512014$

8. Bartlett J., \& Weber D., (2013): Management of healthcare personnel exposed to HIV. Journal of Infectious Diseases; 202(S2): S270-S277.

9. Bouallègue O., Naija W., Said H., Nouria A., Jaidane N., Dhidah L., \& Boujaafar N., (2013): Incidence of ICU-acquired nososcomial infections in University Hospital of Sahloul (Sousse-Tunisia). Antimicrobial resistance and infection control journal V 2(Suppl 1): P233.

10. Cosens B., (2012): Needle-stick guideline. American Journal of Infection Control, v43 (6), p521-525.

11. El Houfey A., (2007): knowledge and practices of dental health care providers towad crossinfection control measures at Assuit city. Thesis submitted for partial fulfillment of the requirements for the master degree in community health nursing department, Faculty of nursing , Assuit University, Egypt,2007.

12. El Sayed M., Anwar M., \& Ahmed M., (2014): Infection control awareness among healthcare providers in family health settings in Shebin Elkom district, Menoufia Governorate, Egypt, Menoufia. Med journal Volume: 27

(4) Page: 840-846.

13. Farrah Lee., BSN \& Natalie Lind, ACE, (2010): The Infection Control Committee; http://www spic.org/AM/Templat.cfm. 
14. Fashafsheh I., Ayed A., Eqtait F., \& Harazneh L., (2015): Knowledge and Practice of Nursing Staff towards Infection Control Measures in the Palestinian Hospitals , Journal of Education and Practice Vol.6(4), 2015

15. Galal W., (2010): occupational exposure to blood and body fluids among health care workers and provision of universal precaution and preventive measures. Thesis submitted for partial fulfillment of the requirements for the master degree of industrial medicine and occupational health department , Faculty of Medicine , Zagazg University, Egypt,2010.

16. Gamal L, (2005): Establishing standards for prevention and control nosocomail infection in the recovery rooms and surgical word at ElMenia University hospital. Thesis for fulfillment of Doctoral degree, Faculty of Nursing , University of Assuit.

17. Girgis H., Youssef W., \& Ali H., (2013): Intensive care nurses' knowledge \& practices regarding infection control standard precautions at a Selected Egyptian Cancer Hospital, a journal of education and practice Vol.4(19).

18. Hafizullah S., Hirosawa T., Higuchi M., AbulBashar M., Djabbarova Z., \& Hamajima N., (2014): Knowledge and practice of universal precautions among health care workers in four national hospitals in Kabul, Afghanistan; J0urnal of Infect Dev Ctries 2014; issue: 4 - volume (8) - pages: 535-542. doi:10.3855/jidc.4143.

19. Katoch V., (2011): Blood Bank Presentation. Available

at:http://www.slideshare.net/vivekkatoch123/blo od-bank

20. Kuhar D., Henderson D., \& Struble K., (2013): Updated US Public Health Service Guidelines for the management of occupational exposure to human immunodeficiency virus and recommendations for post-exposure prophylaxis. Infection Control and Hospital Epidemiology V34 (9), P875-892.

21. Labrague L., Rosales R., \& Tizon M., (2012): Knowledge of and compliance with standard precautions among student nurses. International journal of advanced nursing Studies, Vol 1,pp.84-97.

22. Mohamed F., (2010): Assessment knowledge , practice and attitude of nurses in out patient clinics toward universal precautions at Assuit University Hospitals .thesis submitted for partial fulfillment of the requirements for the master degree of community health nursing department, Faculty of nursing , Assuit University, Egypt,2010.
23. Nour Eldien H., \& Ali R., (2016): Effect of education intervention on prevention of bloodborne infections for healthcare workers in family medicine centers, Suez Canal University in Ismailia City, Egypt, Middle east journal of family medicine vol 14 ( 2), march 2016.

24. Nwogoh B., Aigberadion U., \& Ikenna A., (2013): Knowledge, attitude, and practice of voluntary blood donation among healthcare workers at the University of Benin Teaching Hospital, Benin City, Nigeria Journal of Blood Transfusion Volume 2013(2013), Article ID 797830, 6 pages.

25. Occupational Safety \& Health Administration (OSHA),(2014): Blood borne pathogens standard.

26. Ontario Ministry of Health \& Residential care in Canada, (2011): Infection prevention and control core competencies program. http://www.public healthontario.com.

27. Ragab F., (2015): Impact of educational program on knowledge of employees about glaucoma at Assiut University. Thesis submitted for partial fulfillment of the requirements for doctoral degree in community health nursing department, Faculty of nursing, Assuit University, Egypt, 2015.

28. Reda A., Fisseha S., Mengistie B., \& Michel J., (2010): Occupational exposure and behavior of healthcare workers in Ethiopia. Open access journal V.5(12); 2010 PMC3009714.

29. Saleh D., Elghorory L., Shafik M., \& Elsherbini E., (2009): Improvement of knowledge, attitudes, and practices of health care workers towards the transmission of blood-borne pathogens: an intervention study. Journal of Egypt Public Health Assoc;volum84issue(56):pp423-41.

30. Shafei A., ( 2013): Increasing blood donation in Egypt, The American University in Cairo. Thesis submitted in partial fulfillment of the requirements for the master degree of Public Policy and Administration Department, American University in Cairo.

31. Vaz1 K., McGrowder D., Alexander-Lindo R., Gordon L., Brown P., \& Irving R., ,(2010):Knowledge, awareness and compliance with universal.

32. Yakob E., Lamaro T., \& Henok A., (2015):Knowledge, attitude and practice towards infection control measures among Mizan-Aman General Hospital Workers, South West Ethiopia. Journal of Community Medicine \& Health Education. Vol 5(370). doi:10.4172/21610711.1000370 . 